\title{
THE MORPHOGENESIS OF CIRCUMVALLATE PAPILLAE AND THE DIFFERENTIATION OF TASTE BUDS IN THE CAT IN ONTOGENY
}

\author{
F. TICHY \\ Department of Anatomy, Histology and Embryology University \\ of Veterinary and Pharmaceutical Sciences, 61242 Brno
}

Received August 16, 1991

\begin{abstract}
Tichý F.: The Morphogenesis of Circumvallate Papillae and the Differentiation of Taste Buds in the Cat in Ontogeny. Acta vet. Brno 62, 1992: 19-26.

The development of circumvallate papillae, taste buds and associated structures, i. e., other types of lingual papillae, gll. gustatoriae and their ducts, was studied in the tongues of feline foetuses 31,40 and 48 days old, kittens one day old and adult cats.

Circumvallate papillae were commenced at 40 weeks of foetal age, the encircling furrow and the ducts of gll. gustatoriae developed at 48 days. Fungiform and filiform papillae appeared later.

Taste buds differentiated from day 31 of foetal development. They were first found in the epithelium of the dorsal surface of circumvallate papillae; in the wall epithelium they appeared at 48 days. At the beginning, the cells constituting the buds were uniform in appearance, from day 48 it was possible to distinguish their types. The number of differentiating buds increased within one papilla from day 40 of foetal development.
\end{abstract}

Tongue, circumvallate papilla, taste bud, foetuses, cat

Detailed observations of the lingual mucosa at the light- and electron-microscopy levels made by a great number of author have provided information on the structure and function of various parts of the tongue under both physiological and pathological conditions. A large and comprehensive body of information has been collected on sensory lingual organs, i. e., intraepithelial nerve endings and taste buds, particularly in laboratory animals, primates and man, and also in some lower vertebrates.

Variability in appearance of the lingual surface epithelium has been reported by several authors (Takagi et al. 1976; Nair and Schroeder 1981; Matravers et al. 1982) who related it to the degree of keratinization of epithelial cells. Differences in the keranitization process have been observed even within one papilla (Iida et al. 1985) and accounted for by the presence of different kinds of keratin in cells constituting the rostral and the caudal surfaces of lingual papillae (Farbman 1970). The differentiation of epithelium into two cell populations producing soft and hard keratin, respectively, is reported to occur as early as during the intrauterine development $\left(\mathrm{Ba}^{-}\right.$ ratz and Farbman 1975).

Taste buds have been studies by light and electron microscopy by many authors. Most attention has been paid to the development of these organs in the epithelium of all kinds of lingual papillae in various animal species. The structure of taste buds at both the cellular and subcellular levels and the process of taste perception have also been investigated.

It has been suggested that a taste bud comes to life when epithelial cells get into contact with a nerve fibre (Beidler and Smallman 1965; Farbman 1965, 1969, 1971, 1980; Conger and Wells 1969; Fujimoto and Murray 1970; Takeda 1972, 1976). The relationship of the nerve fibre to the cell and vice versa can be characterized as a permanent state existing in each taste bud and facilitating a continuous exchange of cells (Beidler and Smallman 1965; Adatia and Gehring 1971; Farbman 1980). 
Another view (Pác 1984) based on studies of other organs of perception suggests that the nerve contact first iniciates the formation of a receptor cell which is subsequently innervated.

This study was undertaken to provide detailed data on the development of circumvallate papillae in the cat as a contribution to a better understanding of the morphogenesis of the lingual mucosa in important farm and domestic animals.

\section{Materials and Methods}

The lingual tissue for examination was obtained from feline foetuses at 31, 40 and 48 days after fertilization, from one-day old kittens and adult cats aged 5 years. Three animals from each age group were sampled. Foetal age was estimated on the basis of the crown-rump length (Evans and Sack 1973).

The collected tissue was immediately fixed in neutral formaldehyde $(1.33 \mathrm{~mol} / \mathrm{l})$ and processed and cut in a routine way including a modified method of dehydration in a graded alcohol series (alcohol concentration increased by $0.1 \mathrm{mmol} / 1$ in each subsequent bath).

The sections were stained with haematoxylin and eosin. Some were treated with the green trichrome reagent to visualize connective structures and some were impregnated using the method of Gomori followed by staining with nuclear red. The sections were examined and photographed using a photomicroscope (UNIVAR Reichert).

\section{Results}

Feline foetus at 31 days

The mucosa of the dorsum linguae at the body-root junction was uneven. The unevenness gradually turned into distinct dome-shaped elevations towards the lateral margins of the tongue as well as in the rostral direction (Plate IX, Fig. 1). The junction between the dorsal and lateral surfaces was covered with a mucosa free from elevations.

The mucosal surface was formed by stratified epithelium. This consisted of one or two layers of short cylindrical cells at the lower part and a layer of polyedric cells in the upper part. The former cells showed well-stained cytoplasm with hyperchromatic nuclei, the latter cells had poorly-stained cytoplasm with low chromatin content of the nuclei and were larger in size than the basal cells. The large irregular elevations found at the lateral margins were covered with epithelium whose light surface cells were flattened to the extent of squamous appearance (Plate IX., Fig. 2). This area also showed the presence of elongated light cells passing throught the whole thickness of the epithelium. At their sides there were darker cells with elongated hyperchromatic nuclei (Fig. 2).

The basement membrane separated the epithelium from the layer of connective tissue which produced irregular protrusions against the epithelium. These were the connective stromata of the dome-shaped elevations described above. The lamina propria mucosae appeared uniform in structure over the whole region of the dorsum linguae investigated. No rudiment of the aponeurosis linguae could be seen at this stage (Fig. 1).

Feline foetus at 40 days

The dorsum linguae surface at the body-root junction was broken into many hill-or dome-shaped elevations separated with grooves and furrows of varying depth (Plate X., Fig. 3). Similarly to the previous stage, the |degree of unevenness grew laterally and rostrally. Among smaller and less distinct elevations, larger protrusions, which were the dorsal surfaces of developing circumvallate papillae, could be observed (Fig. 3).

On cross-section, the anlages of circumvallate papillae appeared as well formed 
structures in the lingual mucosa. They were localized at various distances from the median line of the tongue. Each developing papilla was separated from the other still undifferentiated ones with a solid cell band later giving rise to the encircling furrow. The basal part of the band distended in a club-like manner; groups of cells derived from its lower part were extended the deep into the developing tongue musculature (Plate X., Figs 3, 4).

Fungiform papillae, dome-like in appearance, were separated with a shallow groove from the surrounding surface.

The anlages of the other papillary types showed a variety of shapes and the separating epithelial bands differed in size (Figs 3, 4).

The epithelium of the lingual mucosa was composed of a distinct germinative layer consisting of rather small well-stained cells, cylindrical in shape, with hyperchromatic nuclei, and of several superficial layers of cells with poorly-stained cytoplasm and light nuclei. The topmost cells in one or two layers were flattened and their nuclei had spindle-like shapes. The cells, however, did not show any signs of keratinization or desquamation (Plate XI., Fig. 5). The thickness of the surface epithelium varied with a higher epithelium being found on the dorsal surface of circumvallate papilla anlages (Figs 4, 5).

Differentiating taste buds were observed in the epithelium of the dorsal surfaces of developing circumvallate papillae and in the superficial parts of epithelial bands, which would later give rise to the encircling furrows. The distended basal parts of the bands did not contain any bases of taste buds (Figs 4,5). The buds, which were mostly situated in the lower half of the epithelium, did not reach the mucosal surface but were separated from it by two or three layers of flat epithelial cells. The base of the bud lay in the germinative epithelial layer, in some cases it even extended into the papillary stroma and was surrounded with a fold of the basement membrane (Fig. 5). Slim elongated cells with hyperchromatic nuclei were found adjacent to the sides of the bud. At that stage the taste bud cells were uniform in appearance (Fig. 5). On comparison, the bases of buds on the dorsal surface of fungiform papillae were similar in both appearance and a degree of differentiation.

The lamina propria mucosae was rich in blood supply, particularly under the anlages of developing papillae. Close above the developing tongue musculature, it presented as a continuous thick well-stained layer, well discernible in the medial region of the dorsum linguae. This was the rudiment of the aponeurosis linguae (Fig. 3, 4).

\section{Feline foetus at 48 days}

The anlages of circumvallate papillae were the most marked structures of the lingual mucosa at that age. They were localized at various distances from the median line of the tongue; the anlages in a higher degree of morphogenesis were found near the margin of the dorsum linguae. The uneven surface of lingual mucosa around the circumvallate papillae was more pronounced in the lateral parts where the other lingual papillae were commenced but not yet differentiated. Similarly to the previous period, these papillae varied in shape and were separated with grooves and invaginations of different sizes (Plates XI., XII., Figs 6, 7). Fungiform papillae were more extensive and showed a higher degree of differentiation than those in 40-day-old foetuses.

The epithelial bands surrounding the developing circumvallate papillae and later becoming the encircling furrows were well formed. Their basal parts sent out long branched canals, terminated with large clusters of cells, into both the 
lamina propria mucosae and the tongue musculature (Figs 6, 7). Among the cell clusters, mostly near the mucosal surface, oval or rounded fissures varying in size were formed. They were lined with flat cells and separated with thin septa (Figs $6,8)$. Within one band, several fissures were often arranged in a tier.

The epithelium covering the anlages of circumvallate papillae was made up of a distinct germinative layer of cylindrical cells, several layers of polyedric cells and two or theree layers of superficial flat cells (Plate XII., Fig. 8). The undifferentiated papillae were covered with an epithelium similar in structure but markedly lower in thickness. In some areas the superficial epithelial cells began to desquamate.

Differentiating taste buds of typical shape were localized in the epithelium of the dorsal surface of the circumvallate papilla. Their apical parts usually did not reach the mucosal surface. The buds consisted of two cell types: cells with hyperchromatic nuclei and well-stained cytoplasm and those with lighter cytoplasm and lower chromatin content in the nuclei (Fig. 8). The same degree of differentiation was seen in the buds present in the surface epithelium of fungiform papillae.

The stromata of papillary anlages were richly supplied with veins. The rudiment of the aponeurosis linguae was similar in appearance to that described in 40-day-old foetuses (Figs 6, 7).

\section{Kitten one day old}

The dorsal surface of the lingual mucosa included numerous papillae varying in size and shape. In addition to circumvallate papillae, there were fungiform papillae and other slim, high papillae separated from each other with deep narrow depressions. In these finger-like projections it was difficult to determine the papillary type (Plate XIII, Fig. 9). Circumvallate papillae with their dome-shaped appearances were the most distinct structures on the dorsum linguae. The bottoms of encircling furrows showed numerous openings of branched ducts of gll. gustatoriae which extended deep into the lingual musculature. The circumvallate papillae situated medially were smaller than the lateral ones.

The surface of the dorsum linguae was covered with typical squamous stratified epithelium at a thickness equal to that found on the circumvallate, undifferentiated and fungiform papillae (Figs 9, 10). The surface layers showed keratinization which, in some areas, was followed by the desquamation of keratinized cells.

The wall epithelium of circumvallate papillae, particularly in the lower parts near the bottom, contained numerous slim taste buds. These ran through the entire thickness of the epithelium from the basement membrane up to the surface where they formed gustatory pores (Plate XIII, Fig. 10). The dorsal surface of circumvallate papillae bore taste buds only occasionally. The buds were made up of two cell types: cells with dark nuclei and well-stained cytoplasm and light cells with low chromatin content in the nucleus (Fig. 01). The taste buds in the e jithelium of fungiform papillae were arranged in a similar way.

The lamina propria mucosae showed, apart from sectioned ducts of gll. gustatoriae and veirs, lymphocytic infiltrations located to the stromata of circumvallate papillae close under the germinative epithelial layer.

The aponeurosis linguae presented as a solid connective tissue band.

\section{Cat at five years}

The dorsum linguae in the adult cat showed the usual types of papillae. The circumvallate papillae were the predominant structures on the mucosal surface 
studied. Each was surrounded with not a very large encircling furrow; at their bottom there were the openings of ducts of gll. gustatoriae (Plate XIV, Fig. 11). Fungiform and occasional filiform papillae were observed close to the circumvallate ones. Some dorsal surfaces of the circumvallate papillae contained large depressions or narrow invaginations (Fig. 11).

The whole surface of the lingual mucosa investigated was covered with stratified squamous epithelium whose cells underwent keratinization and local desquamation.

Slim taste buds were found in the upper part of the wall epithelium. They communicated with the encircling furrow through the porus gustatorius (Plate XIV, Fig. 12). They were composed of the two cell types described before.

The lamina propria mucosae included veins, areas of glandular parenchyma of gll. gustatoriae, gustatory ducts and patches of adipose tissue (Fig. 11). Lymphocytic infiltrations were found near the openings of gustatory ducts. The aponeurosis linguae had its usual appearance.

\section{Discussion}

The data available on the structures of lingual mucosa based on light- and electron-microscopic studies made in animals (Nair and Schroeder 1981; Matravers et al. 1982; Iida et al. 1985 and others) give only incomplete information on the beginning and progress of differentiation of the lingual structures in farm and domestic animals. Some of our earlier work has already dealt with this issue (Tichý and Černý 1987; Tichý 1991 a, b, c, 1992a, b, c).

Our observations show that the first important changes in morphology of the feline tongue occurred between 31st and 48th days of the prenatal development. This period was characterized by the commencement and development of circumvallate papillae and the appearance of differentiating taste buds in the epithelium. Probably, the first sign of development of the taste bud, similarly to swine (Tichý 1991b), is the presence of light elongated cells on the dorsal surface of primitive dome-shaped elevations which, in the 31-day-old feline foetus, were regarded as the anlages of circumvallate papillae. Elongated cells with more intensive staining attached to the light cells were considered the perigemmal cells (Beidler and Smallman 1965; Farbman 1965a, 1980; Murray and Murray 1970; Takeda 1972, 1976) gradually giving rise to the other types of bud cells, such as dark bud cells according to Farbman (1980). At later stages of differentiation, perigemmal cells of more distinct forms were found adjacent to the taste buds, which is in agreement with the views of other authors (Adatia and Gehring 1971; Farbman 1980) suggesting that taste bud cells are permanently and continually replaced. The occasional finding of lymphocytes in the taste buds of a newly-born kitten is indicative of the process of destruction or reconstruction of the bud. However, since the occasion was very rare, relation of the lymphocytes to some pathological lesion seems to be a more plausible explanation.

Taste buds in the typical elongated spindle-shaped forms were seen in the epithelium of the dorsal surface of circumvallate papillae at 40 days of the prenatal development. Their localization there supports our earlier view (Tichý and Černý 1987; Tichý 1991b) that the buds are first formed on the dorsal surface and "travel" to the wall epithelium later in association with the growth of papillae.

While at 40 days it was impossible to distinguish the cell types reported in electron-microscopic studies of several animal species (De Lorenzo 1958; 
Scalzi 1967; Fujimoto and Murray 1970; Murray et al. 1972; Takeda $1972,1976)$ at 48 days the taste buds showed cells with two kinds of nuclei (hyperchromatic and low chromatin). It is thought that in this period, the differentiation of dark cells (with hyperchromatic nuclei), light cells and perhaps also receptor cells (both with low content of chromatin in the nuclei) was commenced. If, according to some authors (Beidler and Smallman 1965; Farbman 1965a, 1969, 1980; Zalewski 1969, 1970, 1972), the taste bud is initiated by contact of epithelial cells with a nerve fibre, then it remains to be explained what triggers the differentiation of the already formed bud cells into the respective types. The data of Takeda (1977) and Farbman 1980) suggest that not all of the bud cels are derived from one and the same population of epithelial cells (receptor cells may arise from nervous tissue) and this may also indicate their gradual development. Our observations can perhaps be taken as a corroboration of these assumptions.

It is of interest that in the foetal periods studied, majority of the taste buds lacked gustatory pores. This is different from the findings in sheep (Tichý and Černý 1987) and pigs (Tichý 1991b, c) in which the porus gustatorius was observed long before birth. In the cat, as a representative of nidicolous vertebrates, the definite structuring of the bud seems to occur just shortly before birth.

Taste buds were present in the wall epithelium of circumvallate papillae occasionally as early as at day 40 but only in the superficial parts of the epithelial band, which later develops into the encircling furrow, i. e., at the junction of dorsal surface and papillary wall. In lower parts of the wall, taste buds were found at 48 days. The gradual shift of the buds is apparently related to the growth and differentiation of the circumvallate papillae in that period. Similarly to pigs (Tichý 1989, 1991 b, c) in the cat at 48 days, the encircling furrow begins to arise from the underlying solid epithelial band through formation of large fissures or round spaces. These occur most likely due to unequal cohesion between the epithelial cells. The development of the ducts of gll. gustatoriae at this stage is conspicuous. The whole process of formation of the encircling furrow in the cat is comparable with that in sheep (Tichý and Černý 1987) and pigs (Tichý $1991 \mathrm{a}, \mathrm{b}, \mathrm{c})$.

As earlier observed in sheep and swine (Tichý and Černý 1987; Tichý 1991 b, c 1992a) and now in cats, the other lingual papillae differentiated later that the circumvallate ones. This "delay" in development was reflected by a different appearance of the surface epithelium which was noticeably lower than that seen on the circumvallate papillae. Our findings suggest that the morphogenesis of feline lingual papillae is going on after birth, a fact not seen in either sheep or swine. A delayed maturation process of feline lingual mucosa may be a species-specific phenomenon because in both sheep and swine the initial signs of differentiation were found at the beginning of the second third while in the cat at the beginning of the second half of the intrauterine development. These results, however, should be interpreted with regard to the differences between the nidicolous and nidifugous vertebrates because in the former the maturation of all structures generally occurs at a lower rate and often takes place in the postnatal period. 


\section{Morfogeneze hrazené papily a diferenciace chutových pohárků u kočky v ontogenezi}

Vznik a vývoj hrazených papil, chutových pohárků a struktur souvisejících, tj. ostatních typů papil jazyka, gll. gustaroriae a jejich vývodů a vrstvy lamina propria mucosae, byl sledován na jazyku fetů kočky stáři 31, 40 a 48 dnů, kotěte stáŕi 1 den a dospělého jedince.

Hrazené papily se zakládaji ve 40 . dnu vývoje, obkružující brázda a vývody gll. gustatoriae vznikají v 48. dnu vývoje. Ostatní typy papil vznikají později než papily hrazené. Papily hrazené a houbovité se vytvářejí dř́ive než papily mechanické.

Chutové pohárky se diferencují od 31. dne vývoje. Jsou lokalizovány nejprve $\mathrm{v}$ epitelu dorsální plochy hrazené papily; $\mathrm{v}$ epitelu jejich stěn se objevují v 48. dnu. vývoje. Zpočátku jsou základy chươvých pohárků tvořeny buňkami stejného vzhledu. Jejich vzájemné odlišení je možné od 48. dne vývoje. Počet diferencujících se pohárků se $\mathrm{v}$ rozsahu jedné hrazené papily zvyšuje od 40 . dne vývoje.

\section{Морфогенез желобоватого сосочка и дифференциация вкүсовых пүковиц кошки в онтогенезисе}

Возникновение и развитие желобоватых сосочков, вкүсовых лүковиц и сопряженных структур, следовательно, остальных типов папилл языка, gll. gustatoriae и их выходов, а также слоя собственной пластинки слизистой оболочки исследовали на языке плода кошки в возрасте 31, 40 и 48 сүток, котенка в возрасте 1 сутки и взрослой кошки.

Желобоватые сосочки основываются на 40 сүтки развития, окружающая борозда и выходы gll. gustatoriae возникают на 48 сүтки: развития. Остальные типы папилл возникают позже желобоватых сосочков. Желобоватые и грибовидные сосочки образуются раньше механических сосочков.

Дифференциация вкусовых лүковиц происходит с 31 сүток развития. Они расположены сперва в эпителии дорсальной поверхности желобоватого сосочка, в эпителии стенок они появляются на 48 сутки развития. В начале основа вкүсовых лүковиц образована клетками одинакового внешнего вида. Их взаимное различие возможно начиная с 48 сүток развития. Численность дифференцируемых луковиц в масштабе одного желобоватого сосочка үвеличивается с 40 суток развития.

\section{References}

ADATIA, A. K.-GEHRING, E. N.: Proprioreceptive innervation of the tongue. J. Anat., 110, 1971: 215-220

BARATZ, R. S.-FARBMAN, A. I.: Morphogenesis of rat lingual filiform papillae. Am. J. . Anat., 143, 1975: 283-302

BEIDLER, J. M. - SMALLMAN, R. L.: Renewal of cells within taste buds. J. Cell Biol., 27, 1965: $263-272$

CONGER, A. D.-WELLS, M. A.: Radiation and aging effect on taste structure and function. Radiat. Res., 37, 1969: $31-49$

DE LORENZO, A. J.: Electron microscopic observation on the taste buds of the rabbit. J. Biophys. Biochem. Cytol., 4, 1958: 143-150 
EVANS, H. E. - SACK, W. O.: Prenatal development of domestic laboratory mammals. Growth curves, external features and selected references. Anat., Histol., Embryol., 2, 1973: 11-45. (Zbl. Vet. Med. C 2)

FARBMAN, A. I.: Fine structure of the taste bud. J. Ultrastruct. Res., 12, 1965a: 328-350

FARBMAN, A. I.: Electron microscope study of the developing taste bud in rat fungiform papilla. Develop. Biol., 11, 1965b: 110-135

FARBMAN, A. I.: Fine structure of degenerating taste buds after denervation. J. Embryol. Exp. Morph., 22, 1969: 55-67

FARBMAN, A. I.: The dual pattern of keratinization in filiform papillae on rat tongue. J. Anat., 106, 1970: 233-242

FARBMAN, A. I.: Development of the taste bud. In: L. M. Beidler (Ed) Handbook of sensory Physiology, Vol. IV., Chemical Senses, Part 2, Springer, New York, 1971: 51-62

FARBMAN, A. I. : Renewal of taste-bud cells in rat circumvallate papillae. Cell Tissue Kinet., 13, 1980: $349-357$.

FUJIMOTO, S.-MURRAY, R. G.: Fine structure of degenerating and regeneration in denervated rabbit vallate taste buds. Anat. Rec., 168, 1970: 393-414

IIDA, M.-YOSHIOKA, I.-MUTO, H.: Three-dimensional and surface structures of rat filiform papillae. Acta anat., 121, 1985: 237-244

MATRAVERS, J. M.-HEANEY, T. G.-APPLETON, J.: Computer analysis of the surface ultrastructural features of porcine oral mucosa. Archs. oral Biol.. 27, 1982: 481-485

MURRAY, R. G. - MURRAY, A.: The anatomy and ultrastructure of taste endings. In: (ed. by) G. E. W.. Wolstenholme and J. Knight: Taste and smell in vertebrates. London, J. and A. Churchill, 1970: 3-30

MURRAY, R. G.-MURRAY, A.-HELLEKANT, G.: Fine structure of taste buds of rat fungiform papillae. In: Proceedings of the Fourth International Symposium on Olfaction and Taste. Schneider, ed. Stuttgart: Wissenschaftliche Verlagsgesellschaft MBH 1972

NAIR, P. N. R. - SCHROEDER, H. E.: Variation and density of microplication in superficial cells of the normal oral lining mucsoa in the monkey, Macacus fascicularis. Archs. oral Biol., 26, 1981: $837-843$

PÁČ, L.: Contribution to ontogenesis of Merkel cells. Z. mikrosk.-anat. Forsch., 98, 1, 1984: $36-48$

TAKAGI, T.-SAITO, H.-ASO, N.: Mechanism on the differentiation of microridges. Scanning electron microscopy of the surface structures of epithelial cells of the developing human tongue (in Japanese). Jap. J. oral Biol, 18, 1976: 418-434

TAKEDA, M.: Fine structure of developing taste buds in human fetal circumvallate papillae (in Japanese with English summary). Acta anat. nippon., 47, 1972: 325-337

TAKEDA, M.: An electron microscopic study on the innervation in the taste buds of the mouse circumvallate papillae. Arch. histol. jap., 39, 1976: 257-269

TAKEDA, M.: Uptake of 5-hydroxytryptophan by gustatory cells in the mouse taste bud. Arch. histol. jap., 40, 1977: 243-250

TICHYY, F.: Morfogeneze hrazené papily a diferenciace chutových pohárků u prasete $\mathrm{v}$ ontogenezi. Scripta medica Brno, 64, 1, 1991a: 50

TICHÝ, F.: The morphogenesis of circumvallate papillae and the differentiation of taste buds in the pig at 41 to 64 days of prenatal development. Acta vet. Brno, 60, 1991b: 99-110

TICHÝ, F.: The morphogenesis of circumvallate papillae and the differentiation of taste buds in the porcine foetus from day 76. till birth and the adult pig. Acta vet. Brno, 60, 1991c: 307-315

TICHÝ, F.: The morphogenesis of selected lingual papillae in ovine and porcine foetuses observed by scanning electron microscopy. Acta vet. Brno, 61, 1992a: 3-10

TICHÝ, F.: The ultrastructure of taste buds in the newborn lamb. Acta vet. Brno, 61, 1992b: $83-91$

TICHÝ, F.: The ultrastructure of taste buds in the newborn pig. Acta vet. Brno, 61, 1992c: $171-177$

TICHÝ, F.-CERNÝ, H.: The morphogenesis of circumvallate papillae and differentiation of taste buds in sheep ontogeny. Acta vet. Brno, 56, 1987: 261-274

ZALEWSKI, A. A.: Neurotrophic-hormonal interaction of taste buds in the rat's vallate papilla. J. Ne"robiol., 1, 1969: 123-132

ZALEWSKI, A. A.: Role of nerve and epithelium in the regulation of alkaline phosphatase activity in gustatory papillae. Exp. Neurol., 23, 1969: 18-28

ZALEWSKI, A. A.: Regeneration of taste buds in the lingual epithelium after excision of the vallate papilla. Exp. Neurol., 26, 1970: 621-629

ZALEWSKI, A. A.: Regeneration of taste buds after transplantation of tongue and ganglia grafts to the anterior chamber of the eye. Exp. Neurol., 35, 1972: 519-528 


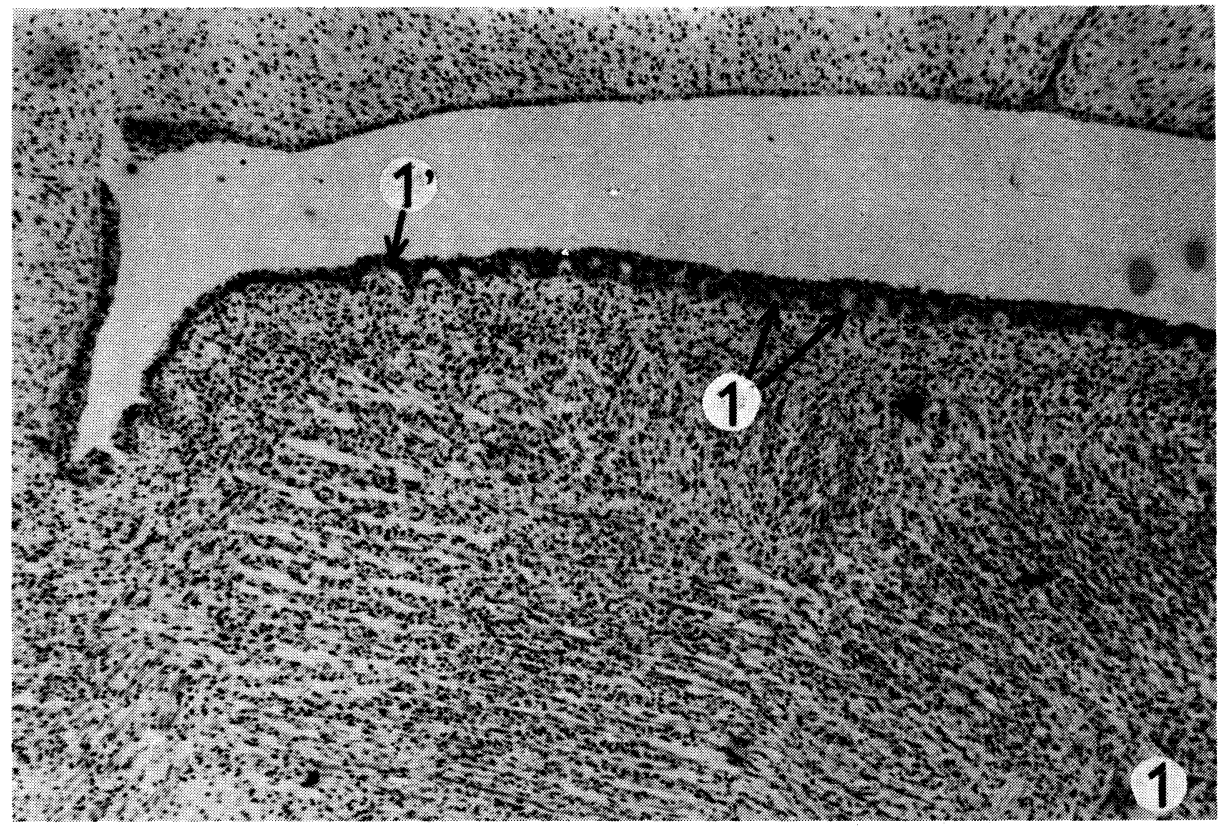

Fig. 1: A cross-section through the oral cavity of a feline foetus aged 31 days. Small dome-shaped elevations in the medial part (1) become more pronounced ad the lateral'margins of the dorsum linguae (1'). HE, $\times 100$.

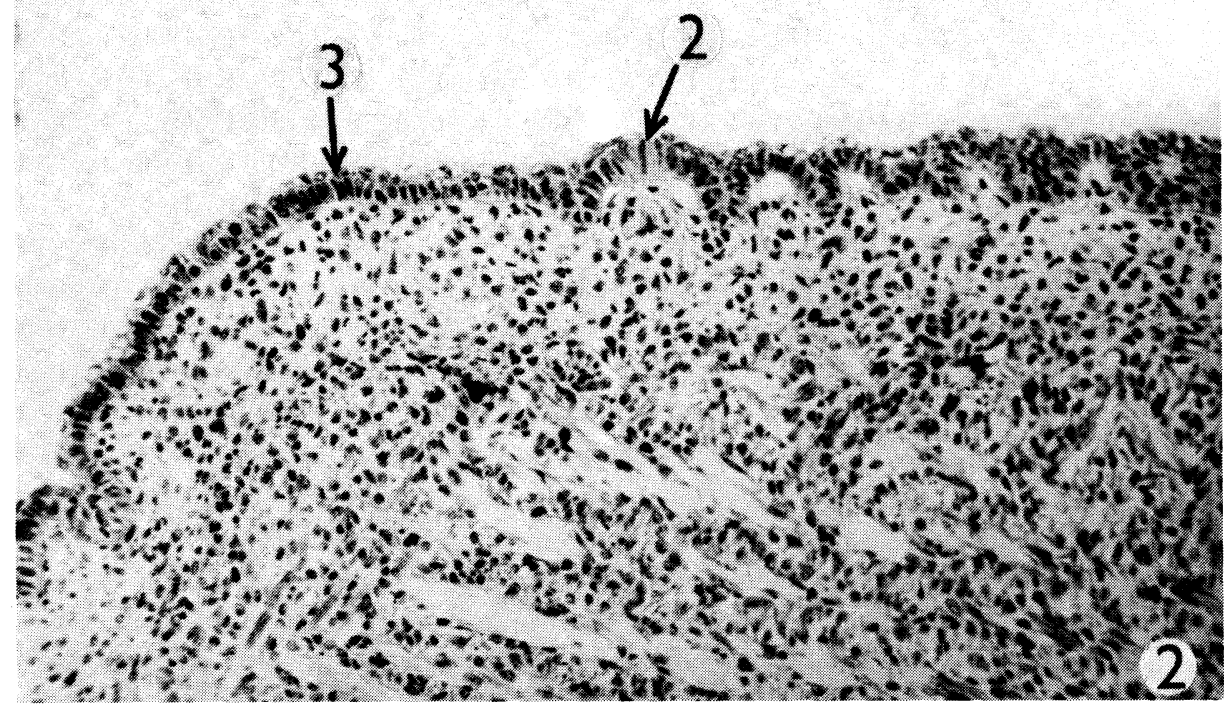

Fig. 2: A detail of Fig. 1. Light elongated cells in the epithelium of the dorsal surface of a primitive papilla (2). A layer of poorly-stained epithelial cells (3). HE, $\times 400$. 


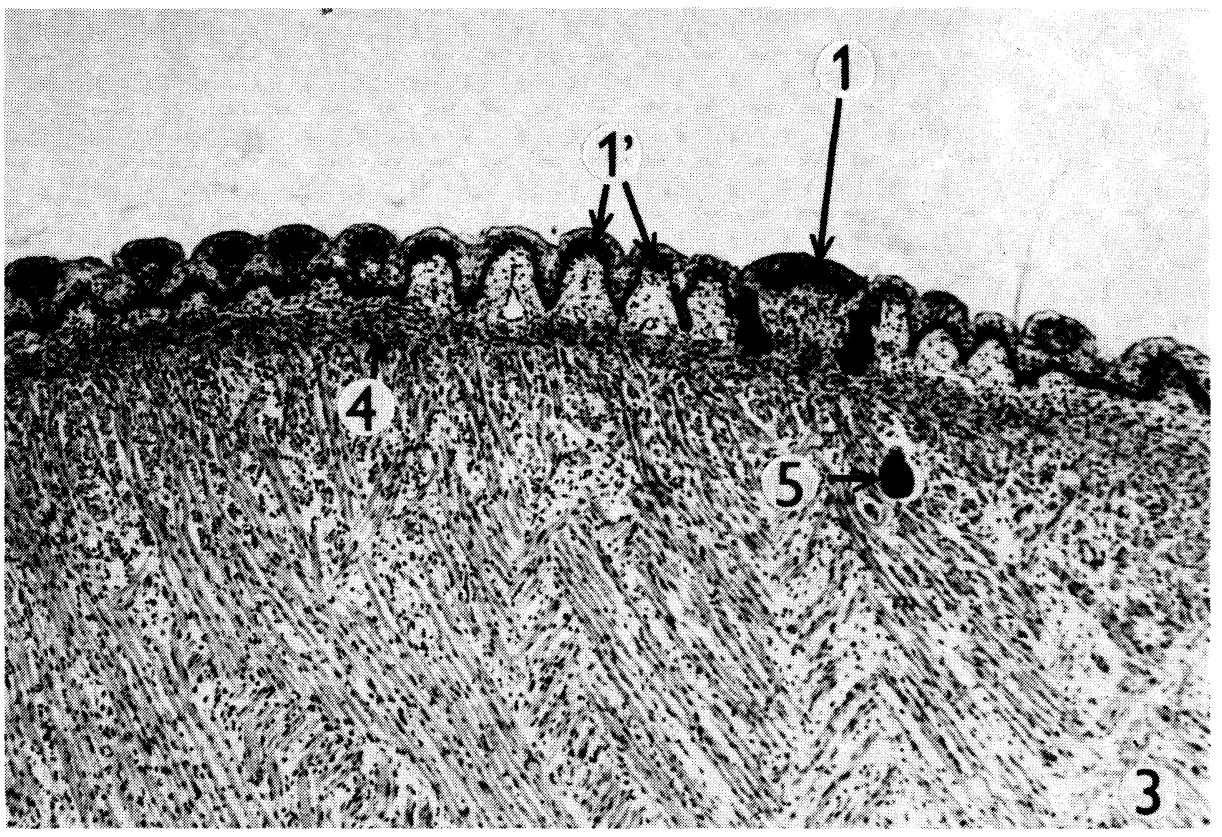

Fig. 3: Dorsum linguae in a 40-day-old feline foetus. Developing circumvallate papilla (1) with numerous undifferentiated papillae (1') around. Gustatory ducts in the process of formation (5). The rudiment of aponeurosis linguae (4). HE, $\times 100$.

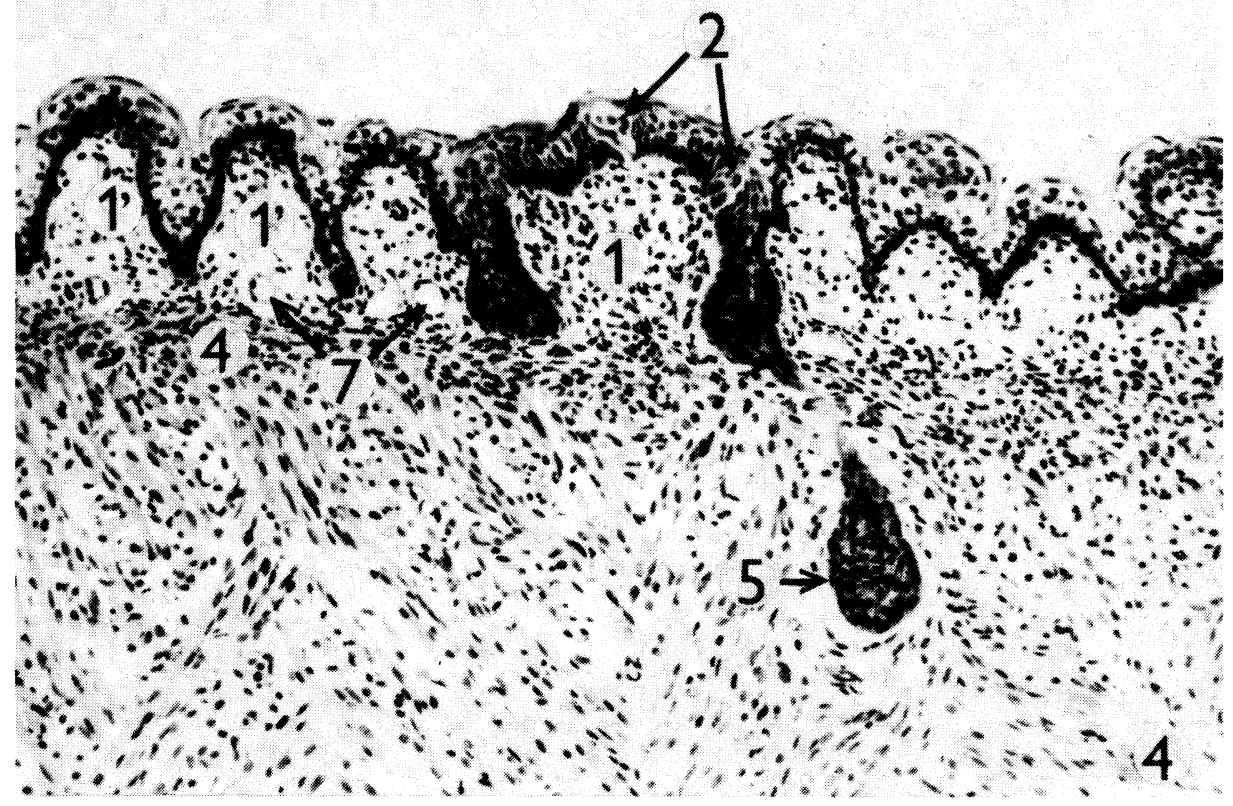

Fig. 4: Developing circumvallate papilla (1) in a 40-day-old foetus. Taste buds (2) are commenced in its epithelium. Undifferentiated papillae (1') with veins in the stroma. Aponeurosis linguae (4). Bases of gustatory ducts $(5)$. HE, $\times 250$. 


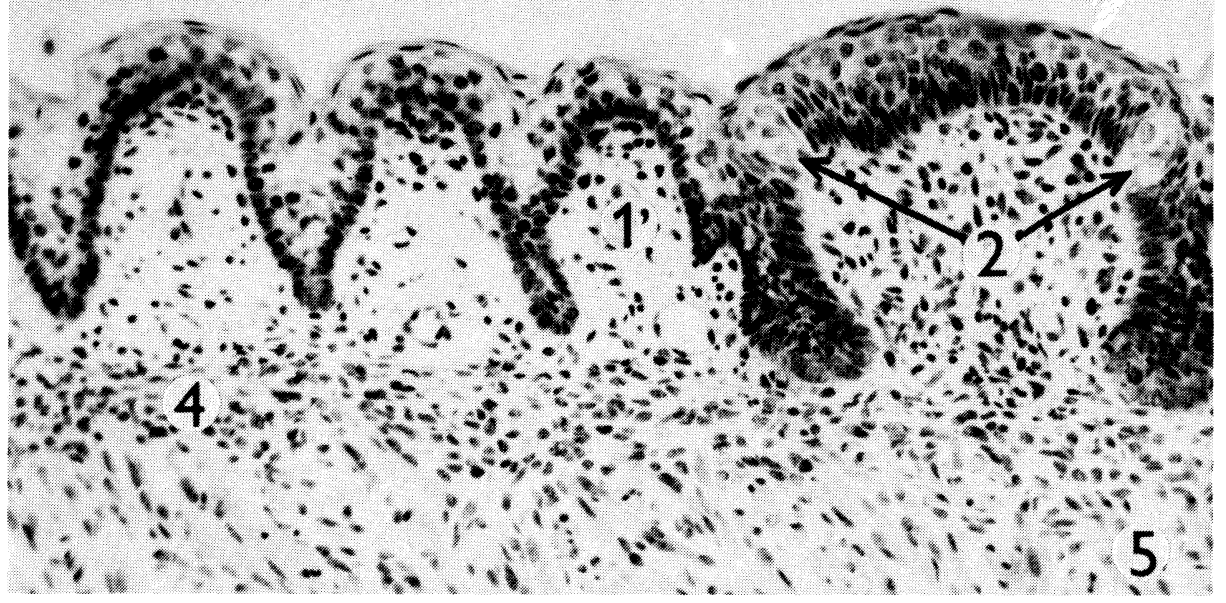

Fig. 5: A detail of the circumvallate papilla in Fig. 3. Taste buds (2) in the epithelium at the margin of the dorsal surface. An undifferentiated papilla (1'). The rudiment of aponeurosis linguae (4). $\mathrm{HE}, \times 400$.

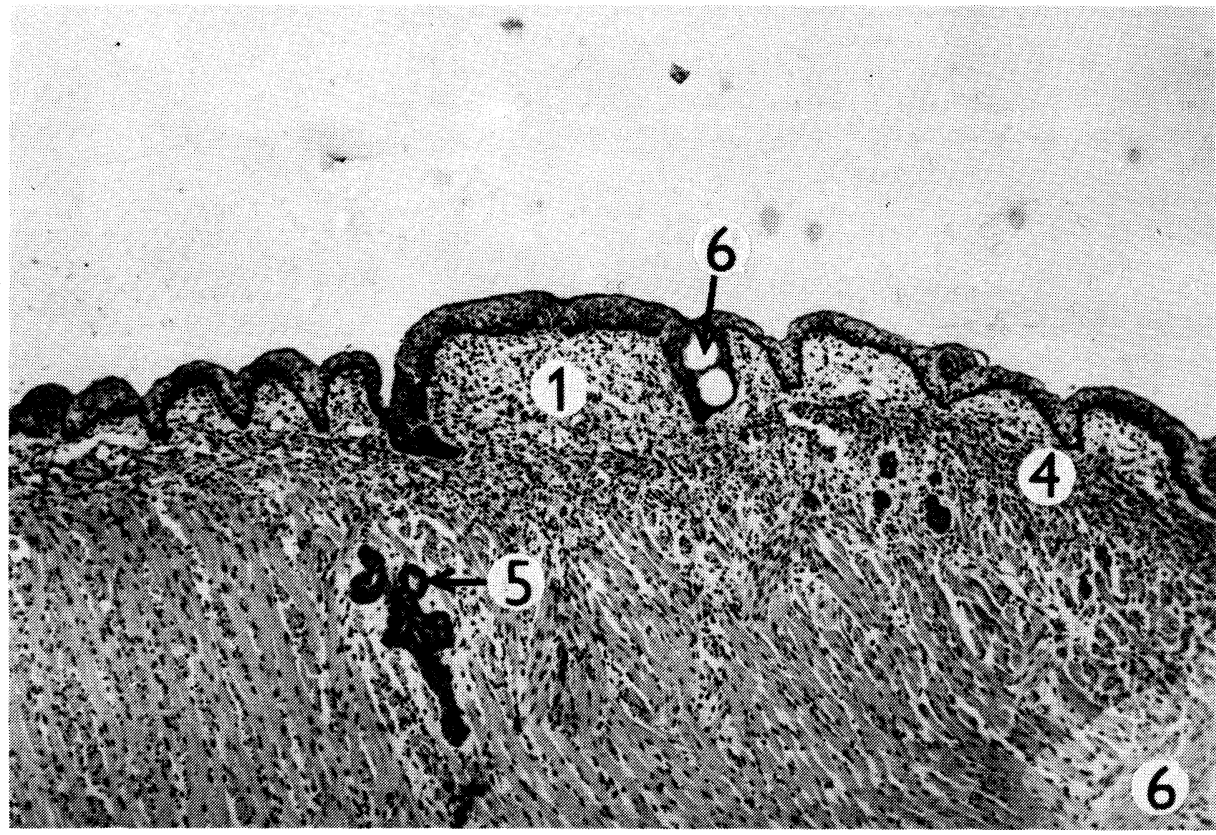

Fig. 6: Dorsum linguae in a feline foetus at 48 days. Circumvallate papilla (1). Large fissures among the cells of the epithelial band in the process of encircling furrow formation (6). Luminized ducts of gll. gustatoriae (5). Aponeurosis linguae (4). HE, $\times 100$. 


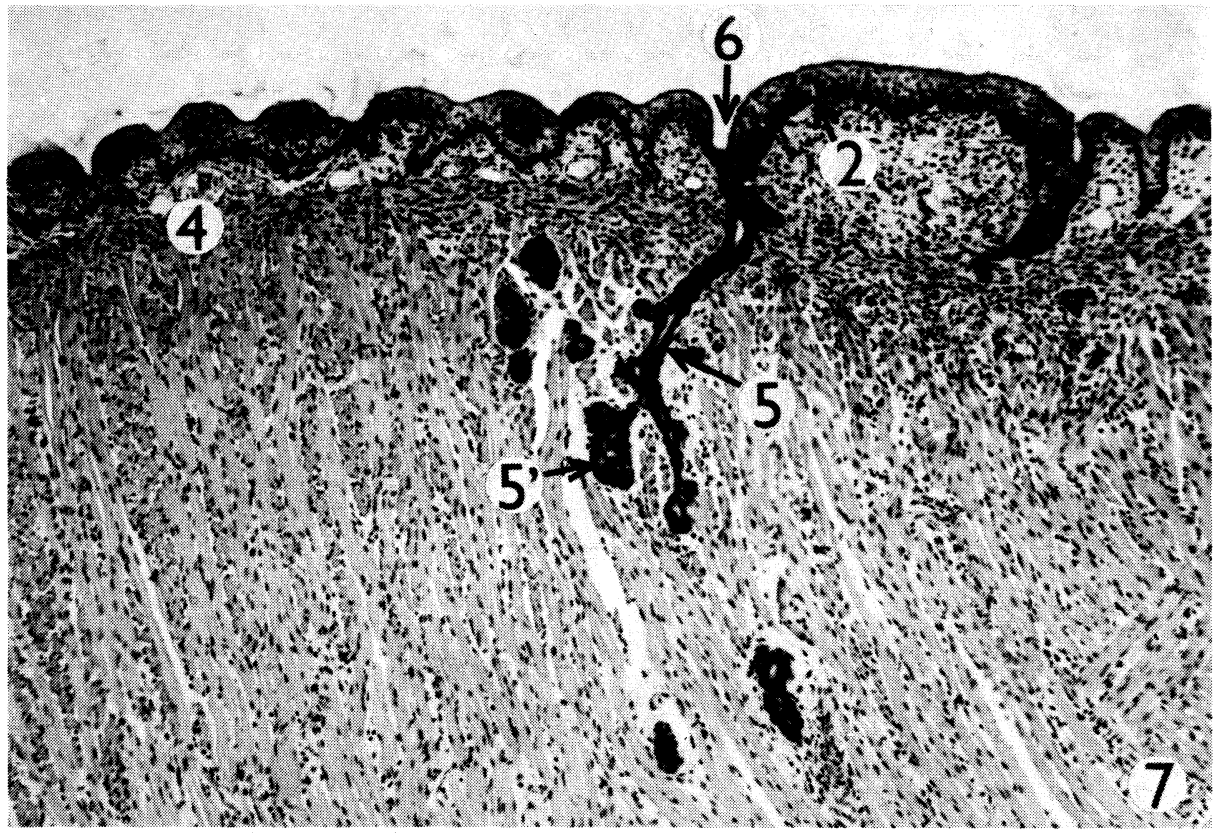

Fig. 7: Dorsum linguae in a feline foetus at 48 days. Taste buds (2) in the epithelium of a circumvallate papilla. Developing encircling furrow (6). Rudiments of secretory parts of gll. gustatoriae (5') and their luminized ducts (5). Aponeurosis linguae (4). HE, $\times 100$.

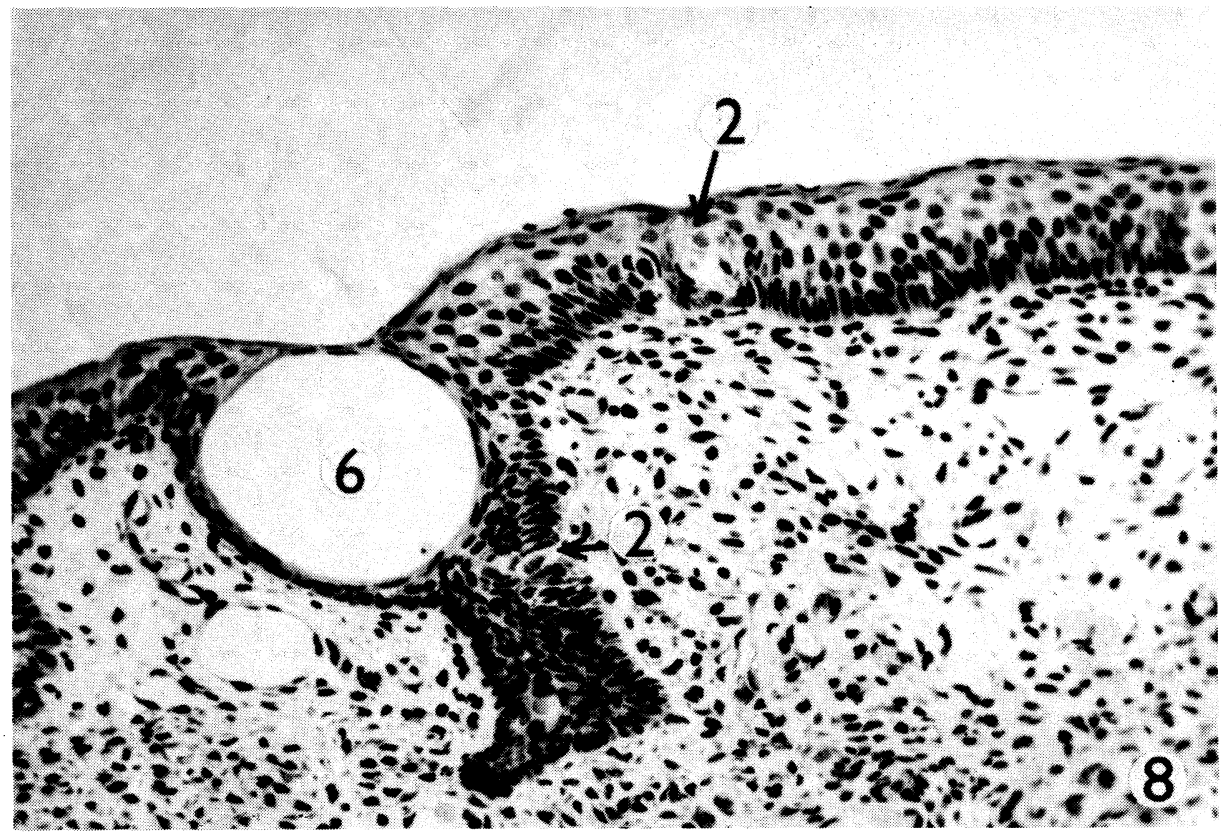

Fig. 8: Part of a circumvallate papilla in 48-day-old feline foetus. Taste buds (2) in the dorsal aspect and the wall epithelium. A large fissure in the epithelial band during formation of the encircling furrow (6). HE, $\times 400$. 


\section{Plate XIII.}

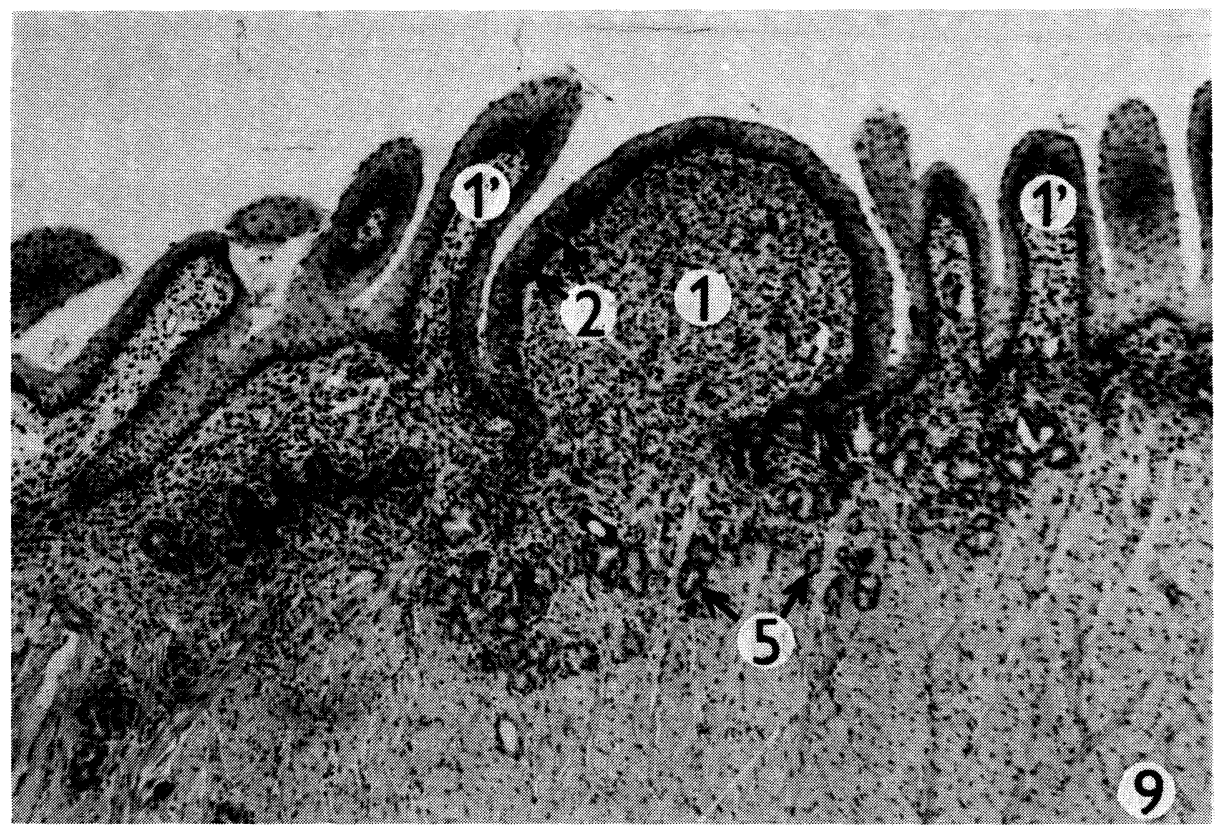

Fig. 9: Circumvallate papilla (1) on the tongue of a day-old kitten. Numerous taste buds (2) in the wall epithelium. Tall filiform papillae (1'). Cross-sections through ducts of gll. gustatoriae (5). $\mathrm{HE}, \times 100$.

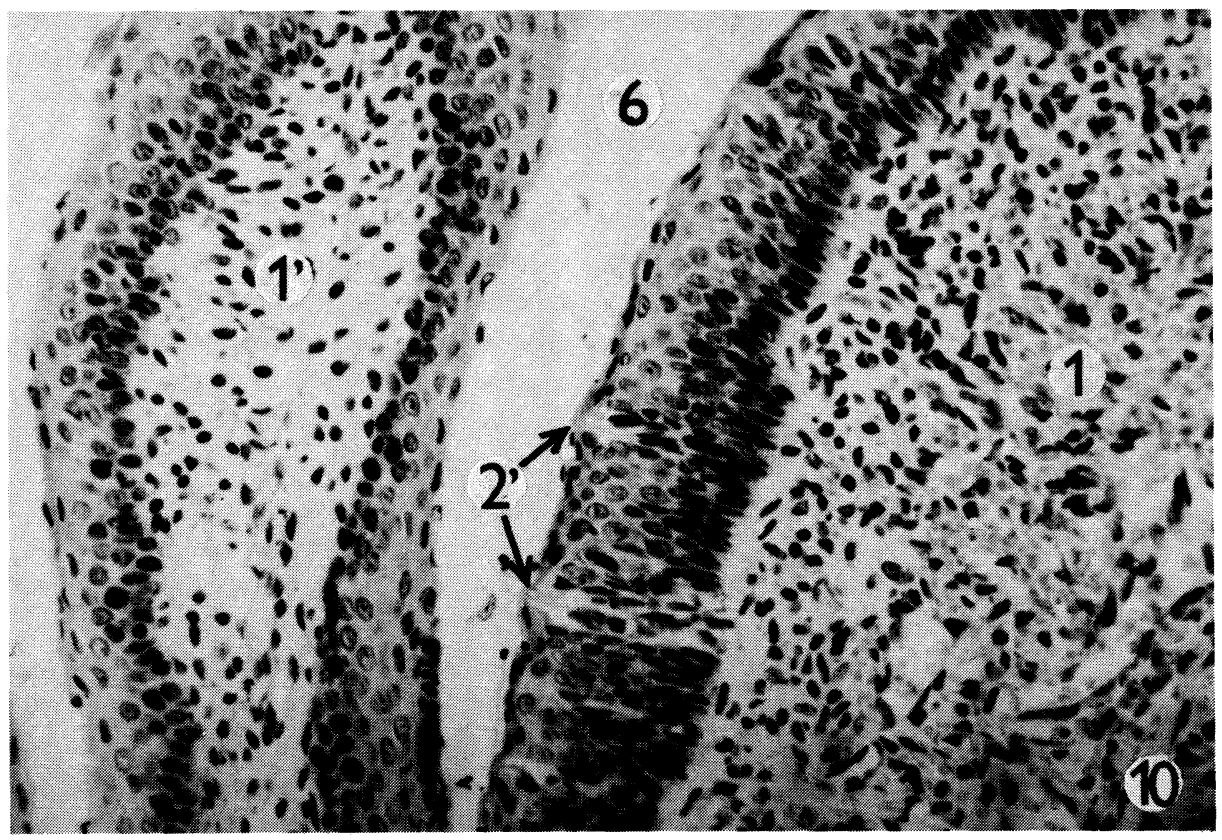

Fig. 10: A detail of Fig. 9. Parts of the circumvallate (1) and the filiform (1') papillae. Taste buds (2') opening into the space of the encircling furrow (6). HE, $\times 400$. 


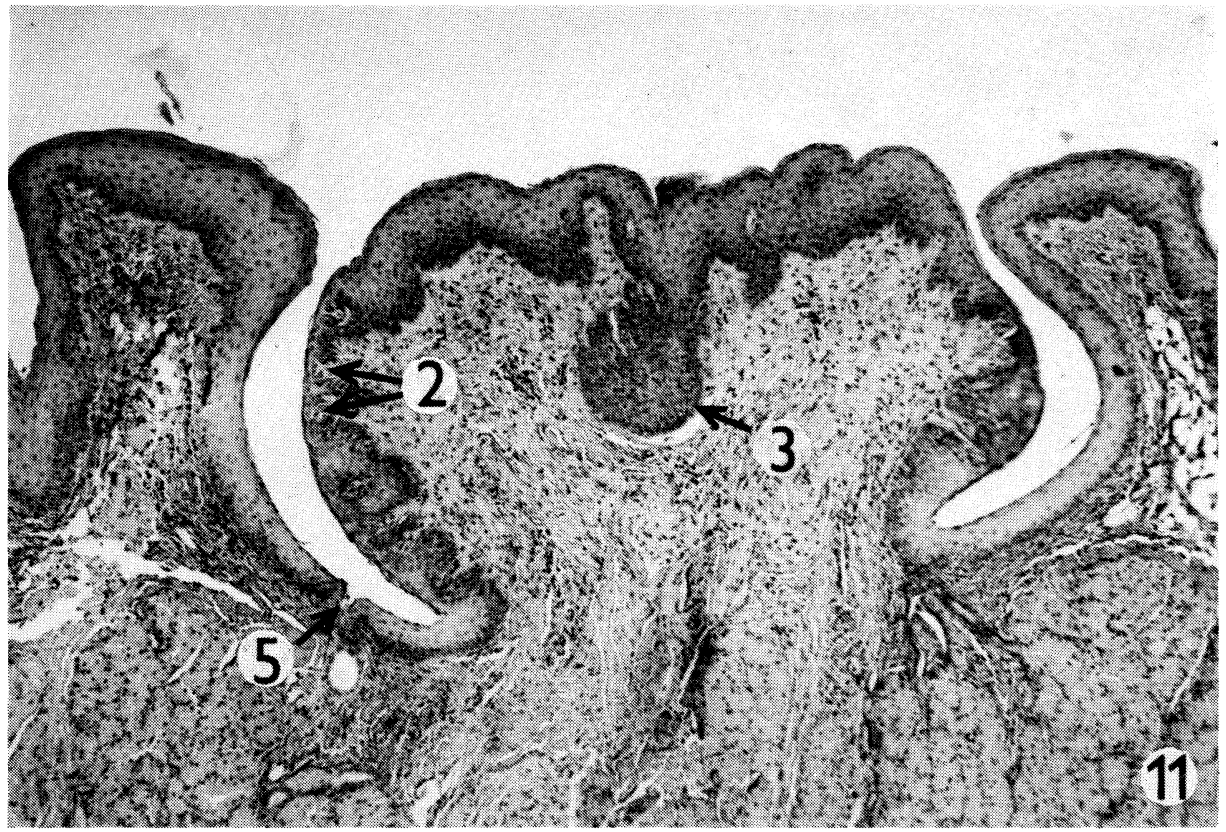

Fig. 11: Circumvallate papilla in an adult cat. Taste buds (2) in the wall epithelium. A fold of epithelium of the dorsal papillary surface (3). Openings of gustatory ducts (5). HE, $\times 100$.

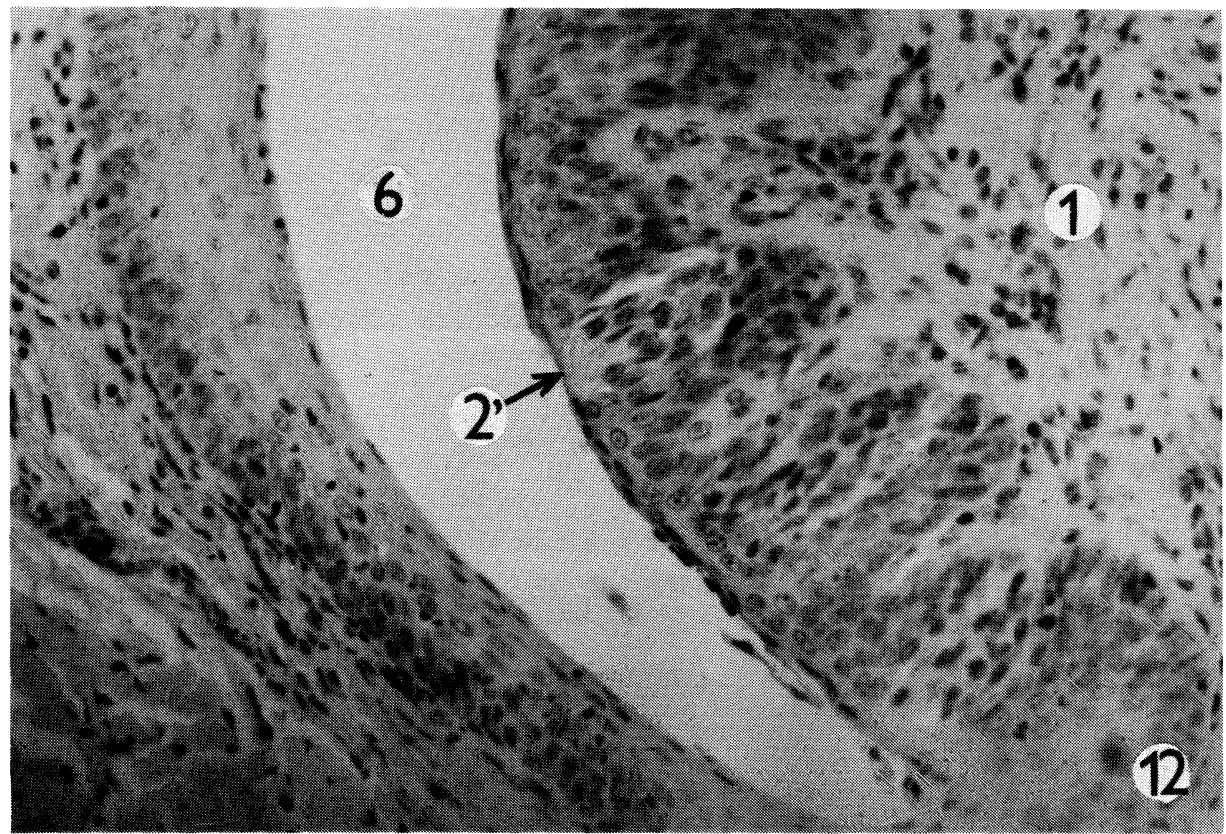

Fig. 12: Peripheral part of the circumvallate papillae from Fig. 11. Encircling furrow (6), taste bud (2'). $\mathrm{HE}, \times 400$. 